\title{
Alterations of the CARD15/NOD2 Gene and the Impact on Management and Treatment of Crohn's Disease Patients
}

\author{
Helga-Paula Török ${ }^{a, b}$ Jürgen Glas ${ }^{a}$ Peter Lohse ${ }^{c}$ Christian Folwacznya,b \\ ${ }^{a}$ Medizinische Klinik und Medizinische Poliklinik - Innenstadt, ${ }^{b}$ Chirurgische Klinik - Innenstadt, and \\ cInstitut für Klinische Chemie - Grosshadern, Klinikum der Universität, München, Germany
}

\section{Key Words}

CARD15/NOD2 - Mutations · Crohn's disease · Genotype, clinical implications

\begin{abstract}
The recent identification of the CARD15/NOD2 gene as a susceptibility locus for Crohn's disease represents an important step towards the delineation of the immunopathogenesis of inflammatory bowel disease. CARD15 functions as an intracellular receptor for bacterial components and thus represents an important link between inflammatory bowel disease and innate immunity. Three major CARD15/NOD2 gene mutations have been associated with Crohn's disease in Caucasians in several independent studies. Together, they explain about $20 \%$ of the genetic susceptibility for Crohn's disease. Genotypephenotype analyses demonstrated an association of these mutations with ileum-specific disease, an increased incidence of the fibrostenotic phenotype and an earlier age of disease onset. Beside these associations, no other relationship between the CARD15/NOD2 genotype and disease behavior or response to treatment has been detailed so far. Thus, the clinical impact of knowing the patient's genotype is limited at this time. Screening for CARD15 mutations in order to identify high-risk individuals or to introduce an individualized disease management is therefore currently not recommended.
\end{abstract}

Copyright @ 2003 S. Karger AG, Basel

\section{Introduction}

The current hypothesis for the pathogenesis of chronic inflammatory bowel disease comprises a loss of tolerance towards luminal antigens in a genetically susceptible host resulting in a chronic, spontaneously relapsing inflammation.

Several lines of evidence are compatible with a significant role of genetic factors in inflammatory bowel disease, especially in Crohn's disease. The most striking example is provided by twin studies, which report concordance rates for Crohn's disease between 42 and 58\% in monozygotic twins [1-4], whereas in dizygotic twins concordance is not significantly enhanced. Epidemiological studies demonstrate a familial aggregation with approximately 5$10 \%$ of all affected individuals reporting a positive familial history of inflammatory bowel disease [5-7]. The relative risk for first degree relatives of patients with Crohn's disease is estimated to be about 15 -fold increased when compared to the general population $[8,9]$. Ethnic differences in the prevalence of the disease further underline the significant role of genetic susceptibility. The highest prevalence rates are reported for Ashkenazi Jews. In African-Americans the rates are lower than in Caucasians, and in Asians the lowest rates have been observed [1015].

For several years, considerable efforts aimed at the identification of the genetic background of inflammatory

PD Dr. med. Christian Folwaczny

Medizinische Poliklinik, Ludwig-Maximilians-Universität München

Nussbaumstr. 20, DE-80336 München (Germany)

Tel. +49 8951602625 , Fax +498951604187

E-Mail Christian.Folwaczny@medinn.med.uni-muenchen.de 


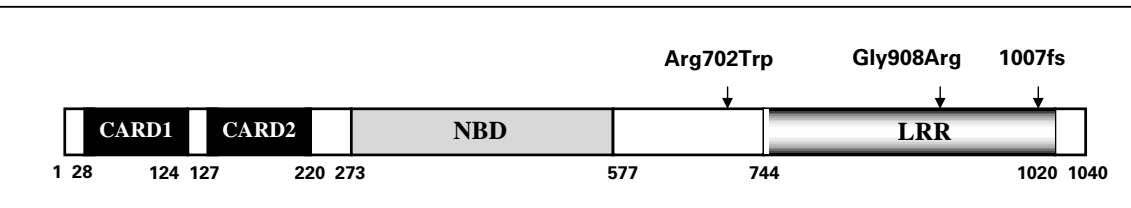

Fig. 1. Structural domains of the CARD15 protein. Like most of the members of the NOD family, CARD15 contains three distinct functional domains: a centrally located nucleotidebinding domain, an amino-terminal effector-binding domain [in the case of CARD15 the two caspase-recruitment domains (CARD)] and a carboxy-terminal ligand-recognition domain [the leucine-rich repeats (LRR)]. The location of the three Crohn's disease-associated variants within the protein are indicated by arrows.

bowel disease. Two complementary approaches, namely genetic linkage analysis and the search for candidate genes, led to the identification of a number of susceptibility loci and to the postulation of functional candidate genes with a presumptive role in immune regulation. The first real breakthrough, however, was achieved only two years ago with the identification of the CARD15/NOD2 gene as the first susceptibility gene with a consistent association with Crohn's disease.

\section{Alterations of the CARD15/NOD2 Gene and Crohn's Disease}

In May 2001, two research groups reported independently that Crohn's disease is associated with mutations in the NOD2 gene, which was later renamed CARD15 $[16,17]$. This association has been confirmed by numerous other studies [18-28].

The CARD15 gene is located in the pericentromeric region of chromosome 16 inside the susceptibility locus displaying the strongest linkage with Crohn's disease [29, 30 ], namely the IBDI locus. It encodes a 1,040-aminoacid protein containing several functional domains: two $\mathrm{N}$-terminal caspase activation and recruitment domains (CARDs), a centrally located nucleotide binding domain (NBD) and a $\mathrm{C}$-terminal leucine-rich repeat domain (LRR) (fig. 1) [31]. Functional studies demonstrated that CARD15 is one of the numerous pattern-recognition receptors implicated in the intracellular sensing of bacterial components [31].

Crohn's Disease-Associated CARD15 Genetic Variants

Three common variants of CARD15 have been linked to the development of Crohn's disease. The most common genetic defect is the frameshift mutation $1007 \mathrm{fs}$
(3020insC) in exon 11, resulting in a premature stop codon and thus in a truncated CARD15 protein. The two other missense mutations are located in exons 4 and 8 and lead to amino acid substitutions Arg702Trp and Gly908Arg, respectively. These three mutations are located in the leucine-rich repeat domain of the CARD15 protein or in its vicinity (fig. 1) and occur on the background of the most common variant Pro268Ser.

Approximately $30 \%$ of Crohn's disease patients carry one and up to $17 \%$ carry two mutated CARD15/NOD2 risk alleles [32]. The allele frequencies reported for Crohn's disease and control populations in a variety of studies are depicted in table 1 . The three above mentioned CARD15 variants seem to confer an increased risk for Crohn's disease only in Caucasians, as these mutations were not detected in populations with a different ethnic background, e.g. in Japanese [33-35], Korean [36] or Chinese [37]. A study in African-Americans with Crohn's disease also reported lower carriage rates of these alleles and the presence of uncommon variants such as Arg790Gln [38]. Among Caucasians, ethnic differences in the allele frequencies have also been reported. Jewish patients have a higher frequency of the Gly908Arg allele and a lower frequency of the Arg702Trp allele, when compared to non-Jewish Crohn's disease patients [26]. The allele frequencies in familial and sporadic Crohn's disease were comparable in two Caucasian cohorts [19,24], whereas in a population of Ashkenazi Jews, familial cases displayed a significantly higher frequency of the Gly908Arg variant than sporadic cases [39].

Having one copy of a mutated CARD15/NOD2 allele confers a 2- to 4-fold increased risk of developing Crohn's disease, whereas having two mutated copies in homozygous or compound heterozygous form increases the risk 20- to 40-fold [16-18]. However, homozygosity for mutant CARD15/NOD2 has also been observed in healthy

\footnotetext{
$\overline{340} \quad \overline{\text { Dig Dis 2003;21:339-345 }}$
} 
Fig. 2. Schematic representation of CARD15 function. Similar to Toll-like receptors on the cell surface, CARD15 functions as a receptor for pathogen-associated molecular patterns (PAMPs) in the cytosol. Recognition of muramyl dipeptide (MDP) derived from bacterial peptidoglycan through the leucin-rich region of CARD15 results in activation of nuclear factor NF- $\kappa \mathrm{B}$ and subsequent initiation of an inflammatory response.

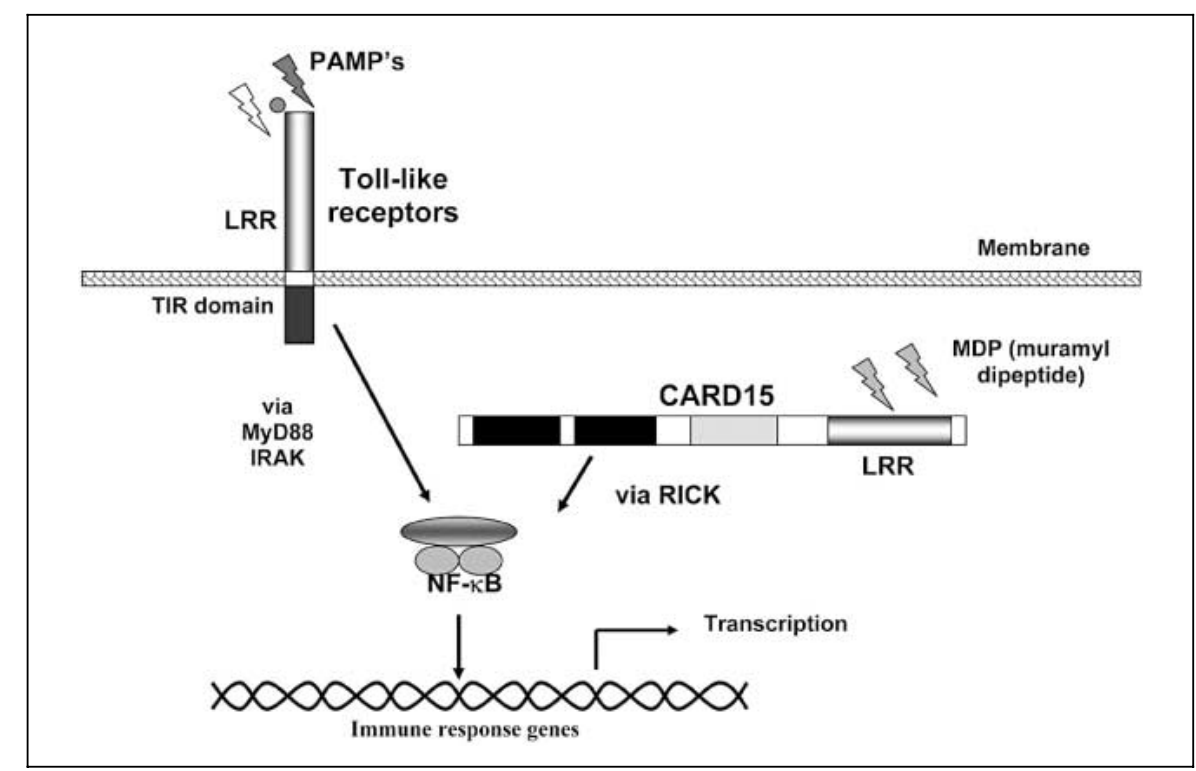

Table 1. Allele frequencies of Crohn's disease-associated CARD15/NOD2 mutations in different studies (\% values)

\begin{tabular}{lllll}
\hline References & Population & \multicolumn{2}{l}{ CARD15/NOD2 mutations } \\
\cline { 3 - 5 } & & $\begin{array}{l}1007 \mathrm{fs} \\
\text { Crohn's disease vs. } \\
\text { (controls) }\end{array}$ & $\begin{array}{l}\text { Gly908Arg } \\
\text { Crohn's disease vs. } \\
\text { (controls) }\end{array}$ & $\begin{array}{l}\text { Arg702Trp } \\
\text { Crohn's disease vs. } \\
\text { (controls) }\end{array}$ \\
\hline Hugot et al. [16] & European & $12(2)$ & $6(1)$ & $11(4)$ \\
Hampe et al. [18] & German/British & $16(4.4)$ & not determined & not determined \\
Lesage et al. [19] & European & $11(2)$ & $6(1)$ & $11(4)$ \\
Ahmad et al. [20] & British & $9.4(1.6)$ & $3.3(1.4)$ & $12.5(5.2)$ \\
Cuthbert et al. [21] & European & $12(2)$ & $6(1)$ & $11(4)$ \\
Vavassori et al. [22] & Italian & $11.6(1.2)$ & not determined & not determined \\
Murillo et al. [23] & Dutch & $8.5(1)$ & $4.3(3)$ & not determined \\
Vermeire et al. [24] & Canadian & $10.3(0.7)$ & $5.2(0.7)$ & $12.9(4.2)$ \\
Radlmayr et al. [25] & German & $14(1.66)$ & not determined & not determined \\
Bonen et al. [26] & US Caucasians & $8.4(4)$ & $4.3(1.7)$ & $10.8(4)$ \\
Cavanaugh et al. [30] & Australian & $7(0)$ & $2(1)$ & $11(5)$ \\
\hline
\end{tabular}

controls [40]. These data suggest that loss-of-function mutations in the CARD15/NOD2 gene are neither necessary nor sufficient for developing Crohn's disease, and that other genetic factors as well as environmental influences are needed for disease manifestation.

Role of CARD15: Link between Genetic Susceptibility and Environmental Factors (e.g. Bacterial Flora)

The CARD15 protein is located in the cytosol and is now recognized as a member of a family of proteins which are involved in intracellular recognition of bacterial components (fig. 2) [41-42]. Although the expression of CARD15 was reported to be restricted to peripheral blood monocytes [31], recent studies have shown basic expression in granulocytes and dendritic cells [43] as well as in several colonic epithelial cell lines and primary intestinal epithelial cells [44]. Moreover, elevated amounts of CARD15 were found in primary colonic epithelial cells $[45,46]$ and in particular in Paneth cells [47] from patients with inflammatory bowel disease. The expression 
of CARD15 can be enhanced by proinflammatory cytokines and bacterial components via Nuclear Factor (NF)$\kappa \mathrm{B}$ activation $[43,45]$.

Functional studies in human embryonic kidney (HEK) 293 T cells transfected with CARD15 revealed that the wild-type protein mediates responsiveness to lipopolysaccharide (LPS) and peptidoglycan (PGN) preparations from several bacteria $[17,26,31,48]$. Recent works identified muramyl dipeptide (MDP), the minimal essential structure of bacterial peptidoglycan, as the moiety specifically recognised by CARD15 $[49,50]$. The three major Crohn's disease-associated variants are defective in their

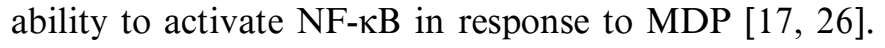
Especially the truncated CARD15 protein, which arises from the 1007 fs mutation, completely lacks this activity $[17,49,50]$. These results were obtained in transfected cells and were subsequently verified by assessment of mRNA expression and protein synthesis of pro- and antiinflammatory cytokines in peripheral blood monocytes from individuals carrying different CARD15 variants [49, Török et al., unpubl. data].

At present, it is not clear how CARD15/NOD2 mutations and the ensuing decreased NF- $\mathrm{KB}$ activation confer susceptibility to Crohn's disease. Assuming that CARD15 is a pattern-recognition receptor, it seems possible that the mutations result in an inadequate innate immune response, e.g. a defective activation of monocytes-macrophages in response to intestinal microbes. This disturbed response could be associated with impaired killing of intracellular microbes resulting in compensatory increase of other components of the immune system such as a marked effector $\mathrm{T}$ cell response [51]. On the other hand, the absence of functional CARD15 in epithelial cells could lead to an impaired secretion of chemokines and defensins in response to microbial products followed by a proliferation of bacteria in the crypts and a loss of barrier function of the mucosa. Several observations support this hypotheses. Hisamatsu et al. [44] showed that CARD15 functions as an antibacterial factor in human intestinal epithelial cells by constraining intracellular bacterial survival and that the $1007 \mathrm{fs}$ mutant lacks this activity. Moreover, a recent communication by Wehkamp et al. [52] reported an impaired expression of antibacterial peptides (defensins) in epithelial cells from Crohn's disease patients carrying CARD15/NOD2 mutations.

The identification of CARD15/NOD2 as a susceptibility locus for Crohn's disease confirms at the molecular level that an inappropriate activation of the mucosal immune system by the intestinal flora plays a causal role in the development of Crohn's disease. Thus, this associa- tion confers an important link between inflammatory bowel disease and innate immunity [53].

\section{Clinical Implications}

Among the cases classified as Crohn's disease, different clinical phenotypes with regard to disease location, extent, aggressiveness, behavior, local and systemic complications as well as varying responses to medical therapy have been described [54]. The observation of conserved phenotypes in multiplex Crohn's disease families [55, 56] is compatible with the assumption that the genetic background influences the phenotype.

Following the identification of CARD15/NOD2 as a susceptibility gene for Crohn's disease, many questions were raised regarding the importance of this discovery for the daily clinical practice. Could mutations in this gene determine the natural history of Crohn's disease? Is the CARD15/NOD2 genotype associated with a specific phenotype, a specific location, extent or aggressiveness of the disease? Can it predict the response to a specific therapeutic agent? Is there a diagnostic role for the mutations? Should we perform screening for CARD15/NOD2 mutants in the general population, in the groups at risk, or in Crohn's disease patients before initiating a specific therapy? Only a few of these questions can be answered satisfactorily at present.

\section{CARD15/NOD2 Genotype and Clinical Course of Crohn's Disease}

Several studies about the relationship between CARD15/NOD2 mutations and the clinical presentation of Crohn's disease have been published. The only consistent finding concerns the disease location, as a number of studies reported a significant association between carriage of one or more CARD15/NOD2 risk alleles and ileal disease. Ahmad and colleagues [20] performed genotypephenotype analysis in 244 extensively characterized Crohn's disease patients with a median follow-up of 16 years. The results demonstrated that CARD15/NOD2 mutations determine ileal disease. Among 429 patients analyzed in a large European study, the frequency of CARD15 mutations was significantly increased in ileumspecific disease, when compared with colon-specific disease ( 26.9 vs. $12.7 \%, p=0.0004)$ [21]. In a French study comprising 166 sporadic and 287 familial cases of Crohn's disease, the patients carrying two risk alleles were characterized by a less frequent colonic involvement than wild-type patients $(p=0.003)$ [19]. The predominance of 
ileal disease in patients carrying mutations in CARD15 was also reported in other studies [24, 57, 58]. Importantly, the association with disease location (ileal and right colonic disease) was the only one also confirmed in a prospective cohort study, in which 106 German and 55 Norwegian patients with Crohn's disease were enrolled [57].

Data concerning disease behavior are more inconsistent. Reasons could be the use of different definitions for the classification as well as the fact that disease behavior changes through time, which underscores the need for long observation periods and illustrates the inherent difficulties of retrospectively differentiating clinical subtypes. Some groups reported an association with the fibrostenotic phenotype [19, 25, 57-59], the presence of fistulas [25, $57-59]$ or the need for surgery $[25,58]$, whereas others did not confirm such findings [20,60].

An earlier age of disease onset in patients carrying two CARD15/NOD2 risk alleles in homozygous or compound heterozygous form has also been reported [19, 20, 61]. Onset of disease occurred approximately 2 years earlier in these patients, when compared with all Crohn's disease patients.

\section{CARD15 and Response to Treatment}

At this time little is known about the influence of CARD15 genotype on the response to medical therapy in Crohn's disease. Vermeire et al. [62] studied the CARD15/NOD2 genotype in 245 patients with Crohn's disease receiving therapy with anti TNF-alpha antibodies (infliximab) and observed no relationship between the presence of mutations and short-term response or response duration. Moreover, the authors could not identify any clinical characteristic which, in combination with CARD15/NOD2 mutations, modified the response to treatment. Similarly, Mascheretti et al. [63] reported no association between the response to infliximab and the CARD1 5 variants in two independent cohorts of 90 and 444 patients with Crohn's disease. These negative findings exclude the three CARD15 mutants as a predictive factor for therapeutic response to infliximab. However, data concerning other therapeutic approaches, such as glucocorticoids, aminosalicylates or immunosuppressors, are lacking so far.

\section{Screening for CARD15/NOD2 Variants?}

One of the major questions raised is whether screening for CARD15/NOD2 genotype in the population at risk or in patients already diagnosed with Crohn's disease should be introduced into the clinical practice.
Giving the limited penetrance and the lack of consistent information about the positive and negative predictive values of genotypes in unaffected relatives (the major risk group), a screening for CARD15/NOD2 variants is currently not recommended. The majority of high-risk individuals will not develop Crohn's disease, as studies in twin siblings demonstrated [64]. Moreover, even if highrisk individuals are detected by genotyping, there are at present no efficient prophylactic methods that could prevent disease onset. Thus, the diagnostic role of CARD15/ NOD2 genotyping is limited. It was suggested that mutation analysis will help to classify undifferentiated colitis cases. However, the low frequency of CARD15/NOD2 mutations in Crohn's disease patients with an ulcerative colitis-like phenotype limits this clinical application [53].

Recommending genotyping in patients already diagnosed with Crohn's disease is also premature. Data about the influence of the genotype on disease behavior are inconsistent and large prospective studies are needed to determine whether mutations in CARD15/NOD2 can predict the prognosis of Crohn's disease, e.g. a more aggressive disease course with need of early immunosuppressive therapy.

In addition, the lack of data regarding the association between CARD15 variants and specific therapeutic responses currently disables the possibility of individualised, genotype-based therapies.

\section{Conclusions}

The association of CARD15/NOD2 mutations with Crohn's disease opens up a new era in the history of inflammatory bowel disease. It shows how the two complementary approaches, linkage analysis and the study of candidate genes can be successfully used in the identification of disease susceptibility genes. The role of CARD15 as a pattern recognition receptor and the loss of function of the genetic variants associated with Crohn's disease establishes a link between innate immunity and chronic bowel inflammation and confirms the pathogenetic importance of luminal bacteria. Moreover, these data are compatible with an immunodeficiency of the mucosal immune system as a pivotal first step in the pathogenesis of Crohn's disease [65]. Although the discoveries are important for understanding the etiology of Crohn's disease, at this time, they have only a modest role in clinical practice. Further studies are needed to clarify the genotype-phenotype relationships and the role of genetic testing in predicting disease behavior. A better understanding 
of the pathophysiologic mechanisms could lead to the development of new prophylactic and therapeutic strategies and to an individualized manner of their application. In case these prophylactic and therapeutic goals are reached, genetic testing for identifying high risk individuals and for predicting response to specific therapies will constitute an important new diagnostic tool for clinicians.

\section{References}

1 Tysk C, Lindberg E, Jarnerot G, FloderusMyrhed B: Ulcerative colitis and Crohn's disease in an unselected population of monozygotic and dizygotic twins: A study of heritability and the influence of smoking. Gut 1988;29: 990-996.

2 Thompson NP, Driscoll R, Pounder RE, Wakefield AJ: Genetics versus environment in inflammatory bowel disease: Results of a British twin study. BMJ 1996;312:95-96.

3 Subhani J, Montgomery SM, Ounder RE, Wakefield AJ: Concordance rates of twins and siblings in inflammatory bowel disease. Gut 1998;42:A40.

4 Halfvarson J, Bodin L, Tysk C, Lindberg E, Jarnerot G: Inflammatory bowel disease in a Swedish twin cohort: A long-term follow-up of concordance and clinical characteristics. Gastroenterology 2003;124:1767-1773.

5 Farmer RG, Michener WM, Mortimer EA: Studies of family history among patients with inflammatory bowel disease. Clin Gastroenterol 1980;9:271-277.

6 Monsen U, Bernell O, Johansson C, Hellers G: Prevalence of inflammatory bowel disease among relatives of patients with Crohn's disease. Scand J Gastroenterol 1991;26:302-306.

7 Russel MG, Pastoor CJ, Janssen KM, van Deursen CT, Muris JW, van Wijlick EH, Stockbrugger RW: Familial aggregation of inflammatory bowel disease: A population-based study in South Limburg, The Netherlands. The South Limburg IBD Study Group. Scand J Gastroenterol Suppl 1997;223:88-91.

8 Orholm M, Munkholm P, Langholz E, Nielsen $\mathrm{OH}$, Sorensen IA, Binder V: Familial occurrence of inflammatory bowel disease. $\mathrm{N}$ Engl $\mathrm{J}$ Med 1991;324:84-88.

9 Peeters M, Nevens H, Baert F, Hiele M, de Meyer AM, Vlietinck R, Rutgeerts P: Familial aggregation in Crohn's disease: Increased ageadjusted risk and concordance in clinical characteristics. Gastroenterology 1996;111:597603.

10 Sonnenberg A, Wasserman ICH: Epidemiology of inflammatory bowel disease among US military veterans. Gastroenterology 1991;101:122130.

11 Kurata JH, Kantor-Fish S, Frankl H, Godby P, Vadheim CM: Crohn's disease among ethnic groups in a large health maintenance organization. Gastroenterology 1992;102:1940-1948.

12 Ogunbi SO, Ransom JA, Sullivan K, Schoen BT, Gold BD: Inflammatory bowel disease in African-American children living in Georgia. $\mathrm{J}$ Pediatr 1998;133:103-107.
13 Yang SK, Loftus EV Jr, Sandborn WJ: Epidemiology of inflammatory bowel disease in Asia. Inflamm Bowel Dis 2001;7:260-270.

14 Roth MP, Petersen GM, McElree C, Vadheim CM, Panish JF, Rotter JI: Familial empiric risk estimates of inflammatory bowel disease in Ashkenazi Jews. Gastroenterology 1989;96: 1016-1020.

15 Yang H, Taylor KD, Rotter JI: Inflammatory bowel disease. I. Genetic epidemiology. Mol Genet Metab 2001;74:1-21.

16 Hugot JP, Chamaillard M, Zouali H, Lesage S, Cezard JP, Belaiche J, Almer S, Tysk C, O’Morain CA, Gassull M, Binder V, Finkel Y, Cortot A, Modigliani R, Laurent-Puig P, Gower-Rousseau C, Macry J, Colombel JF, Sahbatou M, Thomas G: Association of NOD2 leucine-rich repeat variants with susceptibility to Crohn's disease. Nature 2001;411:599-603.

17 Ogura Y, Bonen DK, Inohara N, Nicolae DL, Chen FF, Ramos R, Britton H, Moran T, Karaliuskas R, Duerr RH, Achkar JP, Brant SR, Bayless TM, Kirschner BS, Hanauer SB, Nunez G, Cho JH: A frameshift mutation in NOD2 associated with susceptibility to Crohn's disease. Nature 2001;411:603-606.

18 Hampe J, Cuthbert A, Croucher PJ, Mirza MM, Mascheretti S, Fisher S, Frenzel H, King K, Hasselmeyer A, MacPherson AJ, Bridger S, van Deventer S, Forbes A, Nikolaus S, Lennard-Jones JE, Foelsch UR, Krawczak M, Lewis C, Schreiber S, Mathew CG; Association between insertion mutation in NOD2 gene and Crohn's disease in German and British populations. Lancet 2001;357:1925-1928.

19 Lesage S, Zouali H, Cezard JP, Colombel JF, Belaiche J, Almer S, Tysk C, O’Morain C, Gassull M, Binder V, Finkel Y, Modigliani R, Gower-Rousseau C, Macry J, Merlin F, Chamaillard M, Jannot AS, Thomas G, Hugot JP; EPWG-IBD Group; EPIMAD Group; GETAID Group: CARD15/NOD2 mutational analysis and genotype-phenotype correlation in 612 patients with inflammatory bowel disease. Am J Hum Genet 2002; 70:845-857.

20 Ahmad T, Armuzzi A, Bunce M, MulcahyHawes K, Marshall SE, Orchard TR, Crawshaw J, Large O, de Silva A, Cook JT, Barnardo M, Cullen S, Welsh KI, Jewell DP: The molecular classification of the clinical manifestations of Crohn's disease. Gastroenterology 2002;122: 854-866.

21 Cuthbert AP, Fisher SA, Mirza MM, King K, Hampe J, Croucher PJ, Mascheretti S, Sanderson J, Forbes A, Mansfield J, Schreiber S, Lewis CM, Mathew CG: The contribution of NOD2 gene mutations to the risk and site of disease in inflammatory bowel disease. Gastroenterology 2002;122:867-874

22 Vavassori P, Borgiani P, D'Apice MR, De Negris F, Del Vecchio Blanco G, Monteleone I Biancone L, Novelli G, Pallone E: 3020insC mutation within the NOD2 gene in Crohn's disease: Frequency and association with clinical pattern in an Italian population. Dig Liver Dis: $2002 ; 34: 153$.

23 Murillo L, Crusius JB, van Bodegraven AA, Alizadeh BZ, Pena AS: CARD15 gene and the classification of Crohn's disease. Immunogenetics 2002;54:59-61.

24 Vermeire S, Wild G, Kocher K, Cousineau J, Dufresne L, Bitton A, Langelier D, Pare P, Lapointe G, Cohen A, Daly MJ, Rioux JD: CARD15 genetic variation in a Quebec population: Prevalence, genotype-phenotype relationship, and haplotype structure. Am J Hum Genet 2002;71:74-83.

25 Radlmayr M, Torok HP, Martin K, Folwaczny $\mathrm{C}$ : The c-insertion mutation of the NOD2 gene is associated with fistulizing and fibrostenotic phenotypes in Crohn's disease. Gastroenterology 2002;122:2091-2092.

26 Bonen DK, Ogura Y, Nicolae DL, Inohara N, Saab L, Tanabe T, Chen FF, Foster SJ, Duerr RH, Brant SR, Cho JH, Nunez G: Crohn's disease-associated NOD2 variants share a signaling defect in response to lipopolysaccharide and peptidoglycan. Gastroenterology 2003; 124:140-146.

27 Cavanaugh JA, Adams KE, Quak EJ, Bryce ME, O'Callaghan NJ, Rodgers HJ, Magarry GR, Butler WJ, Eaden JA, Roberts-Thomson IC, Pavli P, Wilson SR, Callen DF: CARD15/ NOD2 risk alleles in the development of Crohn's disease in the Australian population. Ann Hum Genet 2003;67:35-41.

28 Bairead E, Harmon DL, Curtis AM, Kelly Y, O'Leary C, Gardner M, Leahy DT, Vaughan P, Keegan D, O'Morain C, O'Donoghue D, Shanahan F, Parfrey NA, Quane KA: Association of NOD2 with Crohn's disease in a homogenous Irish population. Eur J Hum Genet 2003; 11:237-244.

29 Hugot JP, Laurent-Puig P, Gower-Rousseau C, Olson JM, Lee JC, Beaugerie L, Naom I, Dupas JL, Van Gossum A, Orholm M, Bonaiti-Pellie C, Weissenbach J, Mathew CG, Lennard-Jones JE, Cortot A, Colombel JF, Thomas G: Mapping of a susceptibility locus for Crohn's disease on chromosome 16. Nature 1996;379: 821-823. 
30 Cavanaugh J: IBD International Genetics Consortium: International collaboration provides convincing linkage replication in complex disease through analysis of a large pooled data set: Crohn disease and chromosome 16. Am J Hum Genet 2001;68:1165-1171.

31 Ogura Y, Inohara N, Benito A, Chen FF, Yamaoka S, Nunez G: Nod2, a Nod1/Apaf-1 family member that is restricted to monocytes and activates NF-kappaB. J Biol Chem 2001; 276:4812-4818.

32 Bonen DK, Cho JH: The genetics of inflammatory bowel disease. Gastroenterology 2003;124: 521-536.

33 Inoue N, Tamura K, Kinouchi Y, Fukuda Y, Takahashi S, Ogura Y, Inohara N, Nunez G, Kishi Y, Koike Y, Shimosegawa T, Shimoyama T, Hibi T: Lack of common NOD2 variants in Japanese patients with Crohn's disease. Gastroenterology 2002;123:86-91.

34 Yamazaki K, Takazoe M, Tanaka T, Kazumori T, Nakamura Y: Absence of mutation in the NOD2/CARD1 5 gene among 483 Japanese patients with Crohn's disease. J Hum Genet 2002;47:469-472

35 Sugimura M, Kinouchi Y, Takahashi S, Aihara H, Takagi S, Negoro K, Obana N, Kojima Y, Matsumoto K, Kikuchi T, Hiroki M, Oomori S, Shimosegawa T: CARD15/NOD2 mutational analysis in Japanese patients with Crohn's disease. Clin Genet 2003;63:160-162.

36 Croucher PJ, Mascheretti S, Hampe J, Huse K, Frenzel H, Stoll M, Lu T, Nikolaus S, Yang SK, Krawczak M, Kim WH, Schreiber S: Haplotype structure and association to Crohn's disease of CARD15 mutations in two ethnically divergent populations. Eur J Hum Genet 2003; 11:6-16.

37 Leong RW, Armuzzi A, Ahmad T, Wong ML, Tse P, Jewell DP, Sung JJ: NOD2/CARD15 gene polymorphisms and Crohn's disease in the Chinese population. Aliment Pharmacol Ther 2003; 17:1465-1470.

38 Bonen DK, Nicolae DL, Moran T, Turkyilmaz MA, Ramos R, Karaliukas R, Brant SR, Duerr RH, Kirschner BS, Hanauer SB, Cho JH: Racial Differences in NOD2 variation: Characterization of NOD2 in African-Americans with Crohn's disease. Gastroenterology 2002;122:A29.

39 Zhou Z, Lin XY, Akolkar PN, Gulwani-Akolkar B, Levine J, Katz S, Silver J: Variation at NOD2/CARD1 5 in familial and sporadic cases of Crohn's disease in the Ashkenazi Jewish population. Am J Gastroenterol 2002;97: 3095-3101.

40 Linde K, Boor PP, Houwing-Duistermaat JJ, Kuipers EJ, Wilson JH, de Rooij FW: Card15 and Crohn's disease: Healthy homozygous carriers of the 3020 ins $\mathrm{C}$ frameshift mutation. Am J Gastroenterol 2003;98:613-617.

41 Inohara N, Ogura Y, Nunez G: Nods: A family of cytosolic proteins that regulate the host response to pathogens. Curr Opin Microbiol 2002; $5: 76-80$

42 Girardin SE, Sansonetti PJ, Philpott DJ: Intracellular vs. extracellular recognition of pathogens-common concepts in mammals and flies. Trends Microbiol 2002;10:193-199.
43 Gutierrez O, Pipaon C, Inohara N, Fontalba A, Ogura Y, Prosper F, Nunez G, FernandezLuna JL: Induction of Nod2 in myelomonocytic and intestinal epithelial cells via nuclear factor-kappa B activation. J Biol Chem 2002;277: 41701-41705.

44 Hisamatsu T, Suzuki M, Reinecker HC, Nadeau WJ, McCormick BA, Podolsky DK: CARD15/NOD2 functions as an antibacterial factor in human intestinal epithelial cells. Gastroenterology 2003;124:993-1000.

45 Rosenstiel P, Fantini M, Brautigam K, Kuhbacher T, Waetzig GH, Seegert D, Schreiber S: TNF-alpha and IFN-gamma regulate the expression of the NOD2 (CARD15) gene in human intestinal epithelial cells. Gastroenterology 2003;12:1001-1009.

46 Berrebi D, Maudinas R, Hugot JP, Chamaillard M, Chareyre F, De Lagausie P, Yang C, Desreumaux P, Giovannini M, Cezard JP, Zouali H, Emilie D, Peuchmaur M: Card15 gene overexpression in mononuclear and epithelial cells of the inflamed Crohn's disease colon. Gut 2003;52:840-846.

47 Lala S, Ogura Y, Osborne C, Hor SY, Bromfield A, Davies S, Ogunbiyi O, Nunez G, Keshav S: Crohn's disease and the NOD2 gene: A role for Paneth cells. Gastroenterology 2003; 125:47-57.

48 Chamaillard M, Philpott D, Girardin SE, Zouali H, Lesage S, Chareyre F, Bui TH, Giovannini $\mathrm{M}$, Zaehringer U, Penard-Lacronique V, Sansonetti PJ, Hugot JP, Thomas G: Geneenvironment interaction modulated by allelic heterogeneity in inflammatory diseases. Proc Natl Acad Sci USA 2003;100:3455-3460.

49 Inohara N, Ogura Y, Fontalba A, Gutierrez O, Pons F, Crespo J, Fukase K, Inamura S, Kusumoto S, Hashimoto M, Foster SJ, Moran AP, Fernandez-Luna JL, Nunez G: Host recognition of bacterial muramyl dipeptide mediated through NOD2. Implications for Crohn's disease. J Biol Chem 2003;278:5509-5512.

50 Girardin SE, Boneca IG, Viala J, Chamaillard M, Labigne A, Thomas G, Philpott DJ, Sansonetti PJ: Nod2 is a general sensor of peptidoglycan through muramyl dipeptide (MDP) detection. J Biol Chem 2003;278:8869-8872.

51 Bouma G, Strober W: The immunological and genetic basis of inflammatory bowel disease. Nat Rev Immunol 2003;521-533.

52 Wehkamp J, Harder J, Weichental M, Herrlinger KR, Schmidt M, Schlee M, Nuding S, Schwab M, Schäfferle E, Stallmach A, Fellermann K, Schröder JM, Stange EF: Pathomechanismus des Morbus Crohn mit NOD-2 (CARD15) Mutation: Defiziente mukosale Defensinexpression bei intakter Zytokinexpression. Z Gastroenterol 2003;41:A741.

53 Hugot JP, Zouali H, Lesage S: Lessons to be learned from the NOD2 gene in Crohn's disease. Eur J Gastroenterol Hepatol 2003;15: 593-597.

54 Gasche C, Alizadeh BZ, Pena AS: Genotypephenotype correlations: How many disorders constitute inflammatory bowel disease? Eur J Gastroenterol Hepatol 2003;15:599-606.
55 Lee JC, Lennard-Jones JE: Inflammatory bowel disease in 67 families each with three or more affected first-degree relatives. Gastroenterology 1996;111:587-596.

56 Bayless TM, Tokayer AZ, Polito JM 2nd, Quaskey SA, Mellits ED, Harris ML: Crohn's disease: Concordance for site and clinical type in affected family members - Potential hereditary influences. Gastroenterology 1996;111: 573-579.

57 Hampe J, Grebe J, Nikolaus S, Solberg C, Croucher PJ, Mascheretti S, Jahnsen J, Moum B, Klump B, Krawczak M, Mirza MM, Foelsch UR, Vatn M, Schreiber S: Association of NOD2 (CARD 15) genotype with clinical course of Crohn's disease: A cohort study. Lancet 2002;359:1661-1665.

58 Helio T, Halme L, Lappalainen M, Fodstad H, Paavola-Sakki P, Turunen U, Farkkila M, Krusius T, Kontula K: CARD15/NOD2 gene variants are associated with familially occurring and complicated forms of Crohn's disease. Gut 2003;52:558-562.

59 Abreu MT, Taylor KD, Lin YC, Hang T, Gaiennie J, Landers CJ, Vasiliauskas EA, Kam LY, Rojany M, Papadakis KA, Rotter JI, Targan SR, Yang H: Mutations in NOD2 are associated with fibrostenosing disease in patients with Crohn's disease. Gastroenterology 2002; 123:679-688

60 Louis E, Michel V, Hugot JP, Reenaers C, Fontaine F, Delforge M, El Yafi F, Colombel JF, Belaiche J: Early development of stricturing or penetrating pattern in Crohn's disease is influenced by disease location, number of flares, and smoking but not by NOD2/CARD 15 genotype. Gut 2003;52:552-557.

61 Fidder HH, Olschwang S, Avidan B, Zouali H Lang A, Bardan E, Picard O, Bar-Meir S, Colombel JF, Chowers Y: Association between mutations in the CARD15 (NOD2) gene and Crohn's disease in Israeli Jewish patients. Am J Med Genet 2003;121:240-244.

62 Vermeire S, Louis E, Rutgeerts P, De Vos M, Van Gossum A, Belaiche J, Pescatore P, Fiasse $\mathrm{R}$, Pelckmans P, Vlietinck R, Merlin F, Zouali H, Thomas G, Colombel JF, Hugot JP: Belgian Group of Infliximab Expanded Access Program and Fondation Jean Dausset CEPH, Paris, France: NOD2/CARD15 does not influence response to infliximab in Crohn's disease. Gastroenterology 2002;123:106-111.

63 Mascheretti S, Hampe J, Croucher PJ, Nikolaus S, Andus T, Schubert S, Olson A, Bao W, Fölsch UR, Schreiber S: Response to infliximab treatment in Crohn's disease is not associated with mutations in the CARD15 (NOD2) gene: An analysis in 534 patients from two multicenter, prospective GCP-level trials. Pharmacogenetics 2002;12:509-515.

64 Sartor RB: Clinical applications of advances in the genetics of IBD. Rev Gastroenterol Disord 2003;3(suppl 1):S9-S17.

65 Folwaczny C, Glas J, Torok HP: Crohn's disease: An immunodeficiency? Eur J Gastroenterol Hepatol 2003; 15:621-626. 